\title{
Impact of inorganic salts on vase life and postharvest qualities of the cut flower of Perpetual Carnation
}

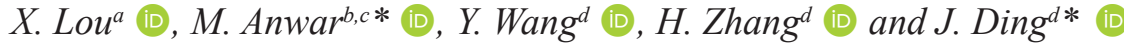 \\ a Shangqiu institute of technology, 236 middle section of suiyang avenue, liangyuan district, shangqiu city, \\ henan province, 476000, China. \\ ${ }^{\mathrm{b}}$ Guangdong Technology Research Center for Marine Algal Bioengineering, Guangdong Key Laboratory of Plant \\ Epigenetics, College of Life Sciences and Oceanography, Shenzhen University, Shenzhen 518060, China. \\ ${ }^{c}$ Key Laboratory of Optoelectronic Devices and Systems of Ministry of Education and Guangdong Province, College of \\ Optoelectronic Engineering, Shenzhen University, Shenzhen 518060, China \\ ${ }^{d}$ Key Laboratory of Plant-Microbe Interactions, Department of Life Science, Shangqiu Normal University, Shangqiu, China \\ *e-mail: caiping0313@163.com, anwar_uaar@yahoo.com
}

Received: March 21, 2019 - Accepted: October 11, 2019 - Distributed: February 28, 2021

(With 7 figures)

\begin{abstract}
This study was carried out in the laboratory of Shangqiu Institute of Technology, Henan to investigate the effect of a different combination of inorganic salt on the quality and physiological characteristics of cut flowers (CFs) of Perpetual Carnation. Furthermore, to find out the best preservation solution of inorganic salt that can enhance the ornamental value of CFs of Carnation and prolong its vase life. Sucrose, 8-hydroxyquinoline, paclobutrazol, salicylic acid and different kinds of inorganic salts were added as a preservation solution. And the same amount of distilled water was used as control. The effects of these various inorganic salts on the morphological characteristics including vase life, changes in flower stems, fresh weight (FW) and water balance and the physiological characteristics including contents of malondialdehyde (MDA), cell membrane permeability and the contents of proline of carnation were investigated. The CFs placed in vase solution with inorganic salts showed significant changes in its morphology and physiological characteristics as compared to control. The changes in flower diameter (FD), FW, malondialdehyde and cell membrane permeability showed an increasing trend first and then decreasing. The value of water balance was observed with a downward trend. However, the vase life, FD, the contents of malondialdehyde, contents of proline and FW of CFs held in the preservative solution containing inorganic salts were increased than that of control. The fresh preservative solution contained sucrose $3 \%+8$-hydroxyquinoline $\left(8\right.$-HQ) $\left(200 \mathrm{mg} \cdot \mathrm{L}^{-1}\right)+$ paclobutrazol $\left(100 \mathrm{mg} \cdot \mathrm{L}^{-1}\right)+$ salicylic acid $(\mathrm{SA})\left(25 \mathrm{mg} \cdot \mathrm{L}^{-1}\right)+\mathrm{CaCl}_{2}\left(100 \mathrm{mg} \cdot \mathrm{L}^{-1}\right) \mathrm{has}$ the best effect on longevity (34 days), FW and FD of carnation CFs. This solution has improved the ornamental and physiological characteristics of fresh carnation CFs.
\end{abstract}

Keywords: Dianthus caryophyllus, cut flower, holding solution, flower longevity, $\mathrm{CaCl}_{2}$, bacterial blockage.

\section{Investigar os efeitos dos sais inorgânicos na vida dos vasos e nas qualidades pós-colheita da flor de corte do Cravo Perpétuo}

\begin{abstract}
Resumo
Este estudo foi realizado no laboratório do Instituto de Tecnologia de Shangqiu, Henan, para investigar o efeito de diferentes combinações de sal inorgânico na qualidade e características fisiológicas de flores cortadas do Cravo Perpétuo. Além disso, para descobrir a melhor solução de preservação de sal inorgânico que pode aumentar o valor ornamental das flores cortadas de Cravo e prolongar a vida do vaso. Sucrose, 8-hidroxiquinolina, paclobutrazol, ácido salicílico e diferentes tipos de sais inorgânicos foram adicionados como uma solução de preservação. E a mesma quantidade de água destilada foi usada como controle. Os efeitos destes vários sais inorgânicos sobre as características morfológicas incluindo a vida dos vasos, alterações nos caules, peso fresco e balanço hídrico e as características fisiológicas incluindo conteúdo de malondialdeído (MDA), permeabilidade da membrana celular e conteúdo de prolina de cravo foram investigados. As flores de corte colocadas em solução de vaso com sais inorgânicos apresentaram mudanças significativas em sua morfologia e características fisiológicas em relação ao controle. As alterações no diâmetro das flores, no peso fresco, no malondialdeído e na permeabilidade da membrana celular mostraram uma tendência crescente primeiro e depois decrescendo. $\mathrm{O}$ valor do balanço hídrico foi observado com tendência de queda. No entanto, a vida útil do vaso, o diâmetro da flor, o conteúdo de malondialdeído, o conteúdo de prolina e o peso fresco de flores cortadas mantidos
\end{abstract}


na solução preservativa contendo sais inorgânicos foram aumentados em relação ao controle. A solução conservante fresca continha sacarose 3\% + 8-hidroxiquinolina (8-HQ) $\left(200 \mathrm{mg} \cdot \mathrm{L}^{-1}\right)+$ paclobutrazol $\left(100 \mathrm{mg} \cdot \mathrm{L}^{-1}\right)+$ ácido salicílico (SA) $\left(25 \mathrm{mg} \cdot \mathrm{L}^{-1}\right)+\mathrm{CaCl}_{2}\left(100 \mathrm{mg} \cdot \mathrm{L}^{-1}\right)$ tem o melhor efeito na longevidade (34 dias), peso fresco e diâmetro de flor de flores cortadas de cravo. Esta solução melhorou as características ornamentais e fisiológicas das flores frescas de cravo.

Palavras-chave: Cravo Perpétuo, flor minimamente cortada, sal inorgânico, vida de vaso, solução de retenção, longevidade da flor, bloqueio bacteriano.

\section{Introduction}

Carnation (Dianthus caryophyllus L.) is a perennial herb of the genus Dianthus. It is one of the most important ornamental flowering plants and broadly used as cut flowers (CFs) (Ali et al., 2008; Onozaki, 2018) and bending plant in orchids. It has a variety of fresh CFs which are consumed in the floriculture market. It is cultivated in many countries and is widely distributed in Fujian, Hubei, Yunnan, Ningxia and other places in China, but China began to study on the fresh CFs relatively late and did not pay enough attention to the various techniques that used for the preservation of fresh CFs. After picking, it is easy to lose water results in wilting, and premature aging affects its ornamental value (Li et al., 2000; Chen et al., 2004). In order to satisfied the consumer's demand for fresh flowers and growers profitability, it is necessary to find the best preservative solution which can prolong the vase life and improve the quality of carnation CFs.

Carnation is one of the most economically important CFs and plays a significant role in the floriculture trade. However, post-harvest senescence occurs within a few days and is a substantial limitation in the marketing of CF of carnation. Generally, early post-harvest senescence is caused by the production of ethylene synthesis. Post-harvest causes petal in rolling, and by the accumulation of bacteria on the cut stem surfaces, which produce extracellular polysaccharides that block xylem vessels and thereby increase hydraulic resistance, subsequently leading to a reduction in water uptake by the stem and premature wilting (van Doorn et al., 1995; Bowyer et al., 2003).

However, the longevity of CFs restricted by several factors such as weight loss and decay, senescence, air embolisms (Jones and Hill, 1993; Van Ieperen et al., 2001; Huang et al., 2002; Bazaid, 2004). These decays are due to bacteria, which present at a high level in preservative holding solution used by farmers, which restrict water supply to ornamental CFs and affect the post-harvest life of ornamental CFs by blocking the vascular system (van Doorn and D'hont, 1994; Loubaud and van Doorn, 2004). This blockage decreases water uptake and result in water-deficient stress, which was articulated in the form of early wilting of ornamental CFs (Put et al., 2000), led to early loss of cell turgidity and might become visible when water uptake and transpiration are out of balance during a lasting period of time, which was the result of an unrecoverable condition and the early end of CFs (Noman et al., 2017) .

The previous study showed that germicide 8-hydroxyqunoline (8-HQ) is vital preservatives used in commercial florist industry (Nowak, 1990). Application of
8-HQ significantly extended the post-harvest life as well as the gain of fresh weight (FW) of CFs of carnation in as compared to control (Nowak, 1990; Knee, 2000). When CFs of chrysanthemum were placed in HQ solution lead to increased its longevity, FW and lowest the water loss (Hussein, 1993). Sucrose acted as the best preservative solution and enhanced the post-harvest life of carnation by reducing ethylene production in petals (Pun et al., 2003). Addition of $\mathrm{CaCl}_{2}$ has prolonged the flowering periods in CFs (Chen et al., 2004).

There are also a lot of researches on how to extend the vase life of carnation CFs. These studies mainly focus on chemical reagents, nutrients, fungicides, temperature, humidity, illumination. Considerable progress has been made (Liu et al., 2009; Kazemi and Ameri, 2012; Ahmad et al., 2014). According to the results of previous studies, the growth process of plants is inseparable from glycogen and various inorganic salts. Glycogen is generally considered to be one of the important substances for maintaining regular respiratory and photosynthesis of plants, but improper use of sucrose will also affect fresh CFs. The life of the bottle insert (Liu et al., 2009), 3\% sucrose proved to have the best preservation effect on fresh CFs of carnations. Inorganic salts are also crucial in maintaining the ornamental and longevity of fresh CFs (Changli, 2007; Yuping, 2009; Edrisi et al., 2012; Anwar et al., 2014). Different inorganic salt ions have different effects on the vase life of fresh CFs. The present study was conducted to evaluate the vase solution with the addition of various inorganic salts on the post-harvest life, quality and ornamental values. Therefore, it is interesting to investigate how holding solutions containg inorganic salts associate to the above mentioned factors that are involved in the process of cut flower senescence. Hence, we tried to study the role of inorganic salts in the process of flower senescence by determing the flower senescence related parameters such as MDA contents, ethylene prododuction, , proline content, water balance, cell membrane permeability, antioxidant activites during flower shelf life of CFs of carnation.

\section{Materials and Methods}

\subsection{Experimental materials}

The fresh CFs of the big red season were used in this experiment. These flowers were purchased from Yiyang Flower Market in Shangqiu City, Henan Province. In this experiment, fresh and healthy plants with relatively uniform appearance and without pests and mechanical damage were selected. The diameter of the flowering branches was cut at an angle of $45^{\circ}$ before the experiment. The diameter of the flowering branches was recorded about $40 \mathrm{~cm}$. The top 
4 leaves were retained in flowering branches. The different chemicals such as sucrose, 8-HQ, paclobutrazol, SA, KCL, $\mathrm{NaCl}, \mathrm{CaCl}_{2}, \mathrm{KALSO}_{4}$ and distilled water were used in the current study.

\subsection{Experimental design}

This experiment consists of five treatments: A, B, C, D and $\mathrm{E}$. $\mathrm{CaCl}_{2}\left(100 \mathrm{mg} \cdot \mathrm{L}^{-1}\right)$ was added to the basic preservation solution in treatment $\mathrm{A}$. On the other hand, $\mathrm{KCL}$ and $\mathrm{NaCl}$ $\left(200 \mathrm{mg} \cdot \mathrm{L}^{-1}\right)$ were added to the basic preservation in treatment B. Likewise, $\mathrm{KALSO}_{4}\left(150 \mathrm{mg} \cdot \mathrm{L}^{-1}\right)$ was added to the basic preservation solution in treatment $C$; the treatment $D$ was treated as a primary preservative, and distilled water was used as a control in treatment E. The preservation solution was poured into a $500 \mathrm{~mL}$ Erlenmeyer flask. Each flask was contained $250 \mathrm{~mL}$ of preservative solution and four carnations. The five replications were carried out in each treatment in this study. After being processed, it is placed in a light-transmitting room with ventilation and no direct light illumination at a temperature of $25 \pm 2{ }^{\circ} \mathrm{C}$ and relative humidity of $60-80 \%$ (Table 1 ).

\subsection{Observation indicators and methods of measurement}

From the day of bottle insertion, the relevant indicators of the morphology and physiological characteristics of the CFs of the four seasons of carnations are regularly measured.

\subsection{Determination of the shape index of fresh CFs of carnation}

Bottle life observe the morphological changes of fresh CFs every day. The life of CFs is regarded as the end of the vase life by $50 \%$ petal loss or wilting (Ding et al., 2011).

\subsection{Flower diameter change}

Method: Using the cross measurement method, the maximum FD of each flower was measured with a ruler at 16:00 every day, repeated twice, and the average value was taken. (Note: When half of each repetition loses its ornamental value, its flower path is no longer measured.)

$$
\begin{aligned}
& \text { Flower dimeter Maximum flower stem } \\
& \text { change rate }(\%)=\frac{\text { average per day }}{\text { Initial flower diameter }} \times 100 \%
\end{aligned}
$$

Fresh weight change and water balance value determination:

The weighing method is used to determine the difference between water absorption and water loss (Zhao et al., 2016). The water absorption and water loss of the fresh CF water level of the carnation were measured at 16:00 every day, and the flower weight was measured.

\subsection{Determination of physiological characteristics of plants}

The content of free proline in plants was determined by the ninhydrin method (Lee, 2000; Li, 2000; Shabnam et al., 2016).

The content of MDA (malondialdehyde) was determined by the thiobarbituric acid method (Draper et al., 1993; Zhao et al., 1994).

Cell membrane permeability was measured by conductivity (Li, 2000).

\subsection{Statistical analysis}

The experimental data were statistically analyzed using SPSS21.0 software, and Excel 2010 was used for chart drawing. The significane differences among th means were anlysed at $\mathrm{P}<0.01$ 0r 0.05 ).

\section{Results and Analysis}

\subsection{Effects of different inorganic salts on the morphological characteristics of fresh CFs of carnation}

\subsubsection{Vase life (days) of Carnation fresh CFs}

Different treatments have different effects on the vase life of carnation fresh CFs (Figure 1). From treatments A to E, the average vase life of carnation fresh CFs was recorded as 34d, 25d, 29d, 26d and 20d, respectively. The vase life was longer in treatment A (Sucrose 3\% + 8-HQ (200 $\mathrm{mg} \cdot \mathrm{L}^{-1}$ ) + Paclobutrazol $\left(100 \mathrm{mg} \cdot \mathrm{L}^{-1}\right)+\mathrm{SA}\left(25 \mathrm{mg} \cdot \mathrm{L}^{-1}\right)+\mathrm{CaCl}_{2}$ $\left.\left(100 \mathrm{mg} \cdot \mathrm{L}^{-1}\right)\right)$ which resulted in $34 \mathrm{~d}$ in comparison with $20 \mathrm{~d}$ of the treatment $\mathrm{E}$ (control). Furthermore, it was observed that the vase life of treatment A was also significantly higher

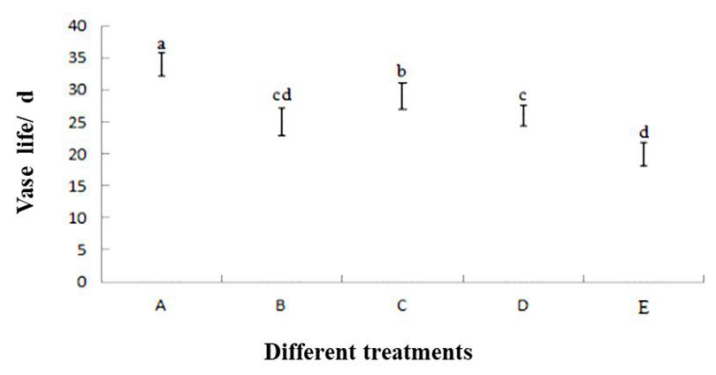

Figure 1. Effect of different treatments on living time of cut carnation flower. Different small letters indicate significant differences between treatments $<0.05$ ).

\begin{tabular}{|c|c|}
\hline Treatment & (Reagent Combination) Fresh liquids \\
\hline $\mathrm{A}$ & Sucrose $3 \%+8$-HQ $\left(200 \mathrm{mg} \cdot \mathrm{L}^{-1}\right)+$ Paclobutrazol $\left(100 \mathrm{mg} \cdot \mathrm{L}^{-1}\right)+\mathrm{SA}\left(25 \mathrm{mg} \cdot \mathrm{L}^{-1}\right)+\mathrm{CaCl}_{2}\left(100 \mathrm{mg} \cdot \mathrm{L}^{-1}\right)$ \\
\hline B & $\begin{array}{l}\text { Sucrose } 3 \%+8-\mathrm{HQ}\left(200 \mathrm{mg} \cdot \mathrm{L}^{-1}\right)+\text { Paclobutrazol }\left(100 \mathrm{mg} \cdot \mathrm{L}^{-1}\right)+\mathrm{SA}\left(25 \mathrm{mg} \cdot \mathrm{L}^{-1}\right)+\mathrm{KCL}\left(200 \mathrm{mg} \cdot \mathrm{L}^{-1}\right) \\
+\mathrm{NaCl}\left(200 \mathrm{mg} \cdot \mathrm{L}^{-1}\right)\end{array}$ \\
\hline $\mathrm{C}$ & Sucrose $3 \%+8$-HQ $\left(200 \mathrm{mg} \cdot \mathrm{L}^{-1}\right)+$ Paclobutrazol $\left(100 \mathrm{mg} \cdot \mathrm{L}^{-1}\right)+\mathrm{SA}\left(25 \mathrm{mg} \cdot \mathrm{L}^{-1}\right)+\mathrm{KALSO}_{4}\left(150 \mathrm{mg} \cdot \mathrm{L}^{-1}\right)$ \\
\hline $\mathrm{D}$ & Sucrose $3 \%+8$-HQ $\left(200 \mathrm{mg} \cdot \mathrm{L}^{-1}\right)+$ Paclobutrazol $\left(100 \mathrm{mg} \cdot \mathrm{L}^{-1}\right)+\mathrm{SA}\left(25 \mathrm{mg} \cdot \mathrm{L}^{-1}\right)$ \\
\hline $\mathrm{E}$ & Distilled water(CK) \\
\hline
\end{tabular}

Table1. The formulae of fresh liquids in each treatment. 
than the other two treatments (B and C) that contained holding solution with inorganic salts. It indicated that a preservative solution contained $\mathrm{CaCl}_{2}$ is the most beneficial to extend the vase life of carnation CFs.

\subsubsection{Changes in the flower diameter of carnation $\mathrm{CFs}$}

Flower path has always been one of the most important morphological indicators of fresh CFs. In this study, The preservative solutions containg inorganic salts promoted the opening of the carnation, vase life of of cut flowers, and the the FD. The trend of FD change, first increased and then decreased. However, the FDs of fresh CFs in different treatments were different. The maximum FD observed in treatment $A$ was $7.15 \mathrm{~cm}$ and followed by $\mathrm{f}$ $7.08 \mathrm{~cm}, 7.01$ and $6.76 \mathrm{~cm}$ in theC treatments B, C and D respectively.. The FD recored in control treatment $(\mathrm{E})$ was $6.83 \mathrm{~cm}$. These results indicated that the addition of $\mathrm{CaCl}_{2}$ in the basic preservative solution increased the $\mathrm{FD}$ of fresh CFs as obserced in tratments (A, B and C). The FD was significantly increased in treatment $\mathrm{A}$ as compared to the control and basic solution without $\mathrm{CaCl}_{2}$ (Figure 2).

Besides, in each treatment, the added value of fresh $\mathrm{CF}$ diameter is also different (Figure 2). The FD in the treatment $\mathrm{A}$ increased by $2.87 \mathrm{~cm}$ compared with the initial FD. Secondly, in the B, C, and D treatments, the FD increased by $2.32 \mathrm{~cm}, 2.07 \mathrm{~cm}$, and $1.39 \mathrm{~cm}$, respectively, compared with the initial FD; increase by $2.33 \mathrm{~cm}$. In each treatment, the FD increased the most in the A treatment, the least FD was observed in the control $\mathrm{E}$, and the maximum increase in the FD was $23.2 \%$ larger than the minimum increase. It can be seen that the preservation liquid with $\mathrm{CaCl}_{2}$ has a better effect on increasing the $\mathrm{FD}$, and the increase is remarkable.

From the change of the trend of the line chart in Figure 2, it can be seen that the different treatments make the time for the four-season carnation fresh CFs to reach the maximum FD and the number of days to maintain the larger FD. In the treatment of A, the fresh CF reached the maximum FD on the $19 \mathrm{~d}$, and the time for maintaining the larger FD was up to 20 days. Therefore, the life of the fresh CF in the A treatment can reach 34d; the B treatment can make the fresh $\mathrm{CF}$ reach the maximum FD at $12 \mathrm{~d}$. However, the B treatment maintained a substantial flower path time of only $12 \mathrm{~d}$, and then the fresh CF died very quickly, and its lifespan was the only $25 \mathrm{~d}$; the $\mathrm{C}$ treatment made the fresh CF reach the maximum FD in $19 \mathrm{~d}$, and the larger FD time was $21 \mathrm{~d}$. The life of fresh CFs was 29d; the maximum FD was reached at $20 \mathrm{~d}$ in D treatment, and the maximum FD was $14 \mathrm{~d}$. In the $\mathrm{E}$ treatment, the fresh CFs reached the maximum FD at $15 \mathrm{~d}$, and the larger FD was maintained for 10d. The results showed that the fresh CF had the longest life in the A treatment with calcium salt preservative solution, up to $34 \mathrm{~d}$. B treatment, that is, the fresh liquid added with potassium salt and sodium salt can quickly promote the bloom of fresh-cut carnation, but not very good. Maintain the life of the carnation CFs. In summary, it can be concluded that the A treatment, that is, the preservation solution of adding calcium salt can maintain the bloom and life span of the fresh CFs of the four-season carnation, maintain the preservation effect, and has the best preservation effect on the fresh CFs of carnation.

\subsubsection{Fresh weight changes of fresh $\mathrm{CFs}$ of four seasons carnations}

The FW of carnation fresh CFs is one of the critical indicators that affect the vase life of CFs. The change of FW in each treatment is consistent with the change of FD. With respect to preservative solution effect on maximum increase of FW of carnation CFs, date presented in Figure 3 indicated that, a significant higher $\mathrm{FW}$ was measured in treatment A (Sucrose 3\% + 8-HQ $\left(200 \mathrm{mg} \cdot \mathrm{L}^{-1}\right)+$ Paclobutrazol $\left(100 \mathrm{mg} \cdot \mathrm{L}^{-1}\right)+\mathrm{SA}\left(25 \mathrm{mg} \cdot \mathrm{L}^{-1}\right)+\mathrm{CaCl}_{2}$ $\left(100 \mathrm{mg} \cdot \mathrm{L}^{-1}\right)$ ) as compared to control. $\mathrm{FW}$ of carnation CFs in treatments $B$ and $C$ was also significantly higher than those of control. The holding solution of treatments A, B and C consist of inorganic salts.

The vase life of CFs is more than $25 \mathrm{~d}$. The FW of the fresh CFs in treatment $\mathrm{E}$ was not apparent, and water loss occurring after $20 \mathrm{~d}$, indicating that the preservation liquid added with inorganic salts was more beneficial to prolong the vase life of the carnation fresh CFs.

It can be seen from the peak in the treatment A(Figure 3), the FW of the fresh CFs of the carnation increased, and the maximum $\mathrm{FW}$ increased by $16 \%$ compared with the initial FW. The maximum FW in treatment $\mathrm{E}$ increased by $2.4 \%$ compared with the initial FW (\%) indicates that the A-preserved fresh-keeping solution, that is, the

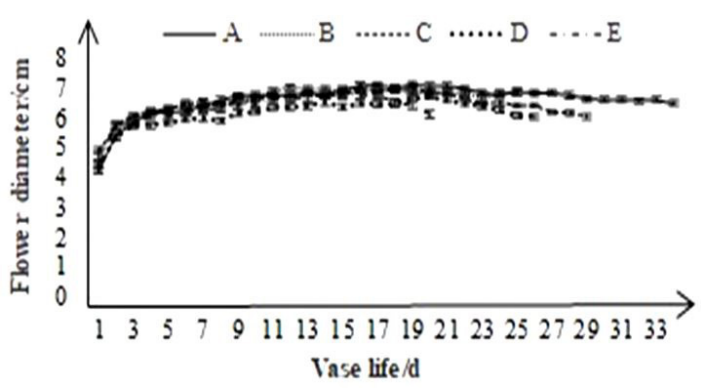

Figure 2. Effect of different inorganic salts on the corolla diameter of cut carnation flower.

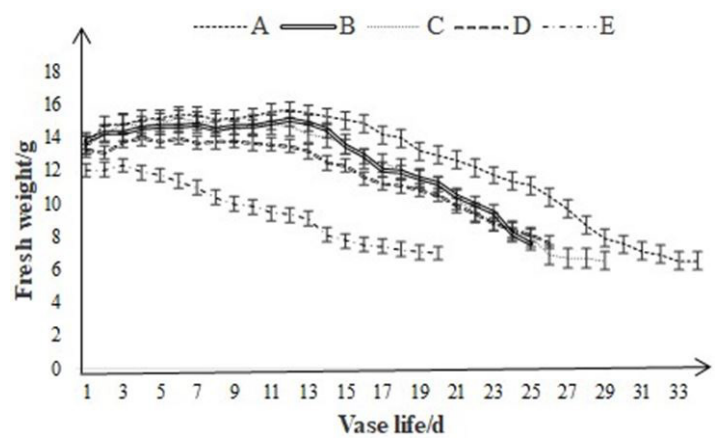

Figure 3. Effects of different fresh liquids on fresh weight of cut carnation flower. 
addition of calcium ions in the basic preservative solution has a great influence on the FW of the fresh CFs of the four-season carnation. In the later stage of the fresh $\mathrm{CF}$, the $\mathrm{FW}$ of the liquid containing the inorganic salt is higher than other controls. And the length of the bottle inserted is long, indicating that the fresh-keeping liquid containing inorganic salt has obvious fresh-keeping effect on the fresh $\mathrm{CFs}$ of the four-season carnation, and the preservation effect of the fresh-keeping liquid added with calcium is the most significant.

\subsubsection{Changes in the value of water balance in carnation $\mathrm{CFs}$}

It was noticed that among the five different treatments, the value of water balance in the fresh CFs of carnation has a decreasing trend (Figure 4). In all treatments, the value of water balance in the early stage of carnation CFs decreased rapidly, positive value; the medium-term decline was slow; the late stage was up and down, which was negative. It can be concluded that in the early stage of bottle insertion, the water absorption of the CF was higher than the water loss, but with the passage of time, the water absorption decreases continuously in the middle and late stages of the bottle insertion, the water loss increases steadily, and the water balance value gradually decreases to negative. In treatments $\mathrm{B}$ and $\mathrm{C}$, the water balance values of the fresh CFs of carnation began to appear negative at $11 \mathrm{~d}$ and $12 \mathrm{~d}$ after the bottle insertion and delayed by $3 \mathrm{~d}$ compared with the control $\mathrm{E}$ on the $9 \mathrm{~d}$. In the treatment $\mathrm{D}$, the water balance value of the fresh CFs of carnation was later than the negative treatment time of the three treatments A, B and C, which was earlier than the negative value of the control $\mathrm{E}$. The overall effect of the treatment $\mathrm{D}$ was good.

In all treatments, the water balance value of carnation $\mathrm{CFs}$ in treatment $\mathrm{A}$ began to appear negative after $13 \mathrm{~d}$ of bottle insertion, which was delayed by $4 \mathrm{~d}$ compared with control treatment $\mathrm{E}$. It can be seen that the holding solution containing $\mathrm{CaCl}_{2}$ is most advantageous for maintaining the stability of the preservative solution.

\subsection{Effects of different inorganic salt on physiological characteristics of carnation CFs}

\subsubsection{The contents of MDA in carnation CFs}

The contents of MDA in the carnation CFs were measured in this experiment. It was noticed that the contents of MDA firstly increased and then decreased in all treatments (Figure 5). In the three treatments of A, B and C containing inorganic salts, the contents of MDA in carnation CFs were measured throughout the experiment. The preservative holding solution containing inorganic salts can reduce the contents of MDA in cutting carnation. This leads to slow down the aging of carnation CFs by increasing the resistant in CFs of the carnation. It was observed in treatment $\mathrm{A}$ that contents of MDA in carnation CFs were lowest, suggesting that $\mathrm{CaCl}_{2}$ is most beneficial to prolong the vase life of $\mathrm{CFs}$ of the carnation.

Below the control, it indicates that the preservative solution containing inorganic salts can reduce the MDA content during the vase cutting of the carnation, increase the resistance of the carnation fresh CFs, and slow down the aging. In each measurement, the MDA content of carnation fresh CFs was the lowest in the treatment of calcium-containing A, indicating that the A-preserved fresh-keeping solution is most beneficial to prolong the vase life of carnation CFs, and the preservation effect is the best.

\subsubsection{Effect of different inorganic salts on cell membrane permeability of carnation fresh $\mathrm{CFs}$}

The poor environment can cause damage to the plasma membrane of the cell, increase in cell membrane permeability, electrolyte extravasations. Extravasations of the electrolyte cause changes in the conductivity of the solution, which in turn reflects the extent of damage to the cell membrane. The higher the conductivity value, the greater the permeability of the cell membrane. The higher the degree, the more ionic extravasations in the cytoplasm and the higher the degree of aging.

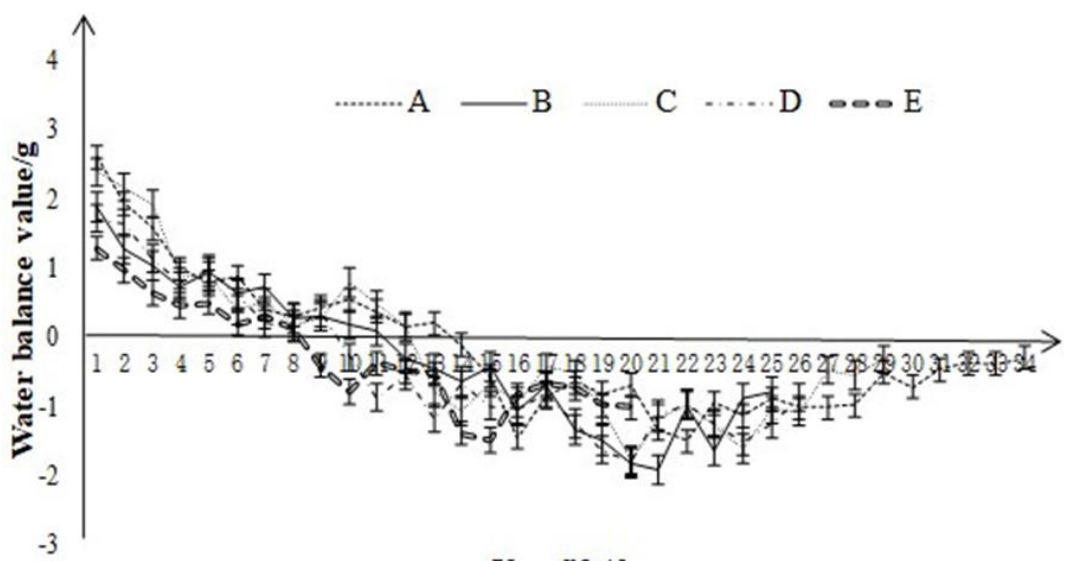

Vase life/d

Figure 4. Effects of different fresh liquids on water balance value of cut carnation flower. 


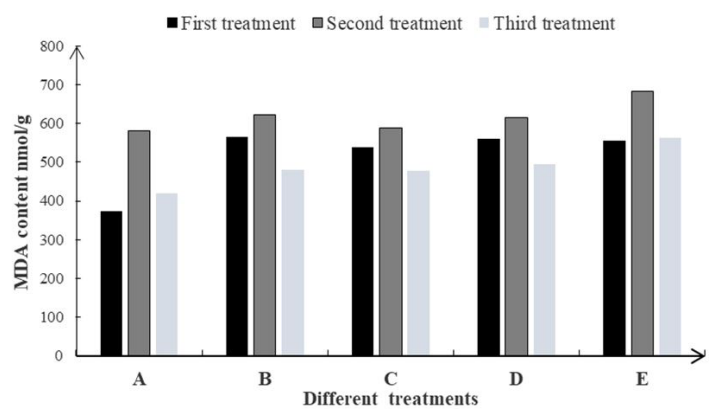

Figure 5. Effects of different fresh liquids on MDA contents of cut carnation flower.

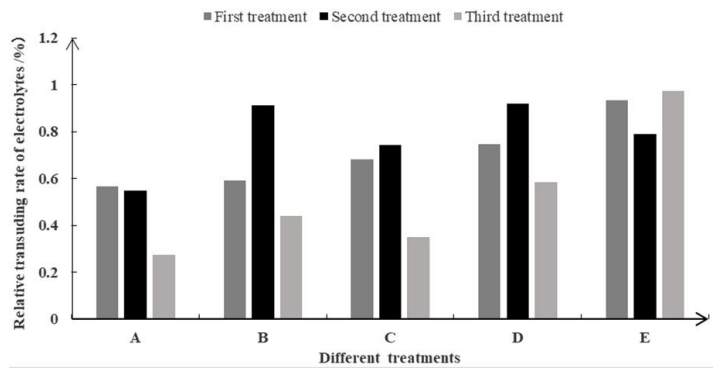

Figure 6. Effects of different fresh liquids on the cell membrane permeability of cut carnation flower.

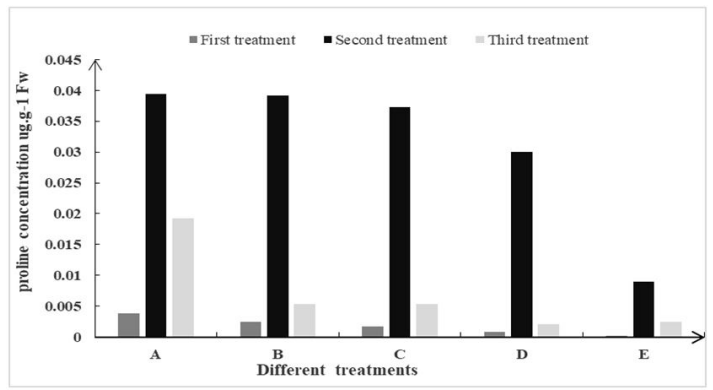

Figure 7. Effects of different fresh liquids on the proline content of cut carnation flower.

It was noticed that the electrolyte of the fresh CFs of the carnation generally increased first and then decreased in all treatments (Figure 6). The treatments A holding solution containing calcium salt minimizes the relative leakage of the flower electrolyte. It concluded that preservative holding solution containing $\mathrm{CaCl}_{2}$ is the most beneficial to keep the flowers fresh.

\subsubsection{Effect of different inorganic salts contents of proline CFs of carnation}

The level of proline in plants is one of the important indicators contributing to the strength of plant stress resistance. To determine the resistance of fresh CFs of carnation in different treatments, the contents of proline in the CFs were chosen as the measurement index. It was observed in all treatments; the contents of proline in the flowers of carnation were first increased and then decreased
(Figure 7). The highest contents of proline in CFs were measured in the early, middle and late stages of bottle insertion in the treatment A. Therefore, it is concluded that the preservative solution containing calcium ions showed the vigorous resistance and is the most helpful to the accumulation of proline in CFs. It is the best preservative solution for CF of carnation.

\section{Discussion}

Fresh CFs are living organisms and play an important role in improving people's living environment and quality of life (Raza et al., 2018) Fresh CFs still have life activities after detaching from the mother plant and continue to consume nutrients. However, CFs unable to continue their normal life activities due to the loss of nutrients such as carbohydrates and inorganic salts (Noman et al., 2017). Several factors including hindering the water absorption by flower stem, dryness of petals, wilting, water loss, reducing of FW (Noman et al., 2018) -dull color, fungal and bacterial infestation at cut sites of the flower branch led to the aging of the CFs. One of the big problems in post-harvest CF physiology is the blockage of the vascular system. Several factors, including air or bacterial growth, plant reaction to the actual cut might be responsible for the blockage of the vascular system. When flower stem detached from the mother plant, certain enzymes are moved to the wounded area, which may produce the chemicals that seal the wound (Loubaud and van Doorn 2004). This phenomenon minimizes water uptake. Water stresses occur due to the blockage of xylem vessels led to early wilting of flowers (Put et al., 2000). The results from this study confirm that exogenous application of different bacterial strains induced a substantial impact on improving the longevity of CFs of carnation.

The ornamental value of fresh CFs is mainly attributed by FD, FW and moisture contents. The CFs have large diameter led to the increase the ornamental value. In this study, maximum FD $(7.15 \mathrm{~cm})$ was obtained in holding solution supplemented with $\mathrm{CaCl}_{2}$ followed by $7.03 \mathrm{~cm}$ and $7.01 \mathrm{~cm}$ in treatments ( $\mathrm{B}$ and $\mathrm{C}$ ) as compared to control $(6.83 \mathrm{~cm})$. In addition, significantly FD $(2.37 \mathrm{~cm})$ increased from initial FD in treatments A in comparison with treatments (D and E). It indicated that FD was significantly higher in treatments having inorganic salts particularly $\mathrm{CaCl}_{2}$. The change of $\mathrm{FW}$ was consistent with the change of FD, as previously reported by (Soad et al., 2011). The results of different concentrations of salicylic acid on the CF of carnations are similar (Anwar et al., 2014). FW loss is one of the most important physiological disorders of ornamental flowers after harvest, which reduced the vase life and quality. To enhance the vase life of CFs, maintain their FW is significant for commercial values (Saeed et al., 2016). Our results showed that minimum flower FW was observed in control treatment (distilled water) and maximum flower FW was observed in treatment A (Figure 3). Generally resulting in higher FW of flowers is considered good because they may result in extending vase 
life compared to those showing fewer ones (Soad et al., 2011). The preservative solution contained $\mathrm{CaCl}_{2}$ with $3 \%$ sucrose decreased flower weight loss. This may be due to the effect of sucrose in delaying petal aging and flower wilting (Halevy and Mayak, 1979). These results are an agreement with (Soad et al., 2011), found that flowers placed in holding solution contained $\mathrm{CaCl}_{2}$ showed higher FW in flowers of Gerbera. Application of inorganic salt in vase solution increased the FW of CFs of Gerbera than control (Shabanian et al., 2018). It can be seen that the holding solution containing $\mathrm{CaCl}_{2}$ is most advantageous for maintaining the stability of the preservative solution.

Water relation is another important factor affecting the longevity of commercial CFs (van Doorn, 2012). After harvesting of CFs, water deficit and wilting of petals occur due to disturbance of water balance that affected by water loss rates and water uptake (Lü et al., 2010). Our results showed that the vase solution contains $\mathrm{CaCl}_{2}$ significantly maintain the water balance than those of control (Figure 4). The data of present study indicated that accumulation of proline in carnation CFs was higher in vase solution with the addition of $\mathrm{CaCl}_{2}$ than water (control) (Figure 7). This result further supported that carnation $\mathrm{CFs}$ in distilled water suffered more severe water than vase solution containing inorganic salts. Proline has been broadly used as a stress indicator for evaluation levels of different stresses including water deficit (Mostofa et al., 2017; Shabanian et al., 2018). The results from our study were in agreement with the results published by previous studies conducted on ornamental CFs, which showed that sufficient water uptake is an essential factor for maintaining a favorable water balance and prolong the vase life of ornamental CFs (Perik et al., 2012; Shabanian et al., 2018).

It is evident from the Figure 1 that maximum vase life of carnation flowers was recorded by using treatment A as compared to control (distilled water). Similar results were obtained by (Soad et al., 2011) on Gerbera and by (Dineshbabu et al., 2002), who demonstrated that similar treatment extended the vase life and improved the flower quality of dendrobium.

Oxidative stress led to senescence in ornamental CFs occurs due to the presence of bacteria and fungi vase solution (Zhang et al., 2011). Antioxidant enzymes are vital in protecting the cell from pathogens by reducing the oxidative stress and water loss (Hoque Hossain et al., 2016; Khalid et al., 2018; Khalid et al., 2019). MDA is a product of membrane lipid peroxidation during the senescence process (Zafar et al., 2019). It maintained the cell membrane system and the plasma membrane integrity during the longevity of ornamental CFs. Its content can reflect the senescence of fresh CFs. The lower contents of MDA in CFs led to delayed aging. In all treatments, the contents of MDA in fresh CFs of carnations increased first and then decreased. Furthermore, application of inorganic salts notably $\mathrm{CaCl}_{2}$ reduced the contents of MDA in carnation CFs as compared water, increased the vase life of carnation CFs. Similar results were observed in gerbera (Shabanian et al., 2018).
The stress resistance slows down it's aging, which is similar to the results of previous studies (Zhao et al., 2016) the effects of five treatments on the cell membrane permeability and proline content of carnation fresh-CFs and their MDA content. The performances of the three treatments (A, B and C) are better than those of the other two treatments, especially the A treatment fresh-keeping solution containing calcium salt.

\section{Conclusion}

In conclusion, longevity and quality of ornamental carnation CFs were related to their efficient ability in water uptake and higher capacity in protecting themselves against pathogen and oxidative stress. Application of inorganic salts, especially $\mathrm{CaCl}_{2}$ as a preservative solution to carnation $\mathrm{CFs}$ prolong the vase life and ornamental values of CFs detached from the mother plant. Treatment A (3\%+8-HQ (200 $\left.\mathrm{mg} \cdot \mathrm{L}^{-1}\right)+$ Paclobutrazol $\left(100 \mathrm{mg} \cdot \mathrm{L}^{-1}\right)$ $+\mathrm{SA}\left(25 \mathrm{mg} \cdot \mathrm{L}^{-1}\right)+\mathrm{CaCl}_{2}\left(100 \mathrm{mg} \cdot \mathrm{L}^{-1}\right)$ significantly increased the vase life of carnation CFs by reducing the water deficit, MDA contents, stresses and maintaining water balance as compared to control. It may also be due to the significantly alleviated bacterial related blockage in the end stem of carnation.

\section{Acknowledgements}

This work was supported by the 2018 Henan Provincial Youth Cadre Teacher Training Program 2018GGJS191. Key scientific research Projects in Henan province under grant (18A180028)

\section{References}

AHMAD, I., DOLE, J.M., VILORIA, Z. and BLAZICH, F.A., 2014. Postharvest performance of cut carnation, chrysanthemum and rose as influenced by conventional and organic floral preservatives. Biological Agriculture and Horticulture, vol. 30, no. 2, pp. 109118. http://dx.doi.org/10.1080/01448765.2013.878880.

ALI, A., AFRASIAB, H., NAZ, S., RAUF, M. and IQBAL, J., 2008. An efficient protocol for in vitro propagation of carnation (Dianthus caryophyllus). Pakistan Journal of Botany, vol. 40, no. 1 , pp. 111 .

ANWAR, M., SAHITO, H.A., HASSAN, I., ABBASI, N.A., AHMED, H.A., BHATTI, M.A., HUSSAIN, A., IQBAL, Z., HUSSAIN, A. and ABRO, A., 2014. Effect of pre harvest treatment of salicylic on growth and vase life of tuberose with aroma environment. Wudpecker Journal of Agricultural Research, vol. 3 , no. 2 , pp. 50-57.

BAZAID, S., 2004. Protein and DNA fragments variation in relation to low temperature in four Rosa hybirida cultivars in Taif, Saudi Arabia. Journal of the Egyptian Academy for Development, vol. 5, pp. 77-90.

BOWYER, M., WILLS, R., BADIYAN, D. and KU, V.V.V., 2003. Extending the postharvest life of carnations with nitric oxide: comparison of fumigation and in vivo delivery. Postharvest Biology and Technology, vol. 30, no. 3, pp. 281-286. http://dx.doi. org/10.1016/S0925-5214(03)00114-5. 
CHANGLI, Z., 2007. Effect of CaCl 2 Combining with B 9 on the fresh preservationg of cut Carnation flowers. Anhui Nongye Kexue, vol. 35, no. 2, pp. 333.

CHEN, D.-S., WANG, J.-M., DING, Y.-X., 2004. A review of senescence and preservation of fresh cut flowers. Yaredai Zhiwu Kexue, vol. 33, no. 1, pp. 73-76.

CHEN, D., LI, N., WANG, J., DING, Y. and WANG, X.1., 2004. Effect of calcium chloride on preservation of cut-flowers of $\{\backslash$ sl Gerbera hybrida\}. Yunnan Zhi Wu Yan Jiu, vol. 26, no. 3, pp. 345-348.

DINESHBABU, M., JAWAHARLAL, M., and VIJAYAKUMAR, M., 2002. Influence of holding solutions on the post harvest life of Dendrobium hybrid sonia-17. South Indian Horticulture, vol. 50, no. 4-6, pp. 451-457.

DING, Y.H., LIU, X.M., and ZHANG, G.H., 2011. Effect of different preservations on freshing-keeping of Carnation cut flowers. Modern Horticulture, vol. 9, pp. 3-4.

DRAPER, H., SQUIRES, E., MAHMOODI, H., WU, J., AGARWAL, S. and HADLEY, M., 1993. A comparative evaluation of thiobarbituric acid methods for the determination of malondialdehyde in biological materials. Free Radical Biology \& Medicine, vol. 15, no. 4, pp. 353-363. http://dx.doi. org/10.1016/0891-5849(93)90035-S. PMid:8225017.

EDRISI, B., SADRPOOR, A. and SAFFAR, V.R., 2012. Effects of chemicals on vase life of cut carnation (Dianthus caryophyllus L.'Delphi') and microorganisms population in solution. Journal of Ornamental and Horticultural Plants, vol. 2, no. 1, pp. 1-11.

HALEVY, A.H. and MAYAK, S., 1979. Senescence and postharvest physiology of cut flowers, part 1. Horticultural Reviews, vol. 1, pp. 204-236. http://dx.doi.org/10.1002/9781118060742.ch5.

HOQUE, T.S., HOSSAIN, M.A., MOSTOFA, M.G., BURRITT, D.J., FUJITA, M. and TRAN, L.S., 2016. Methylglyoxal: An emerging signaling molecule in plant abiotic stress responses and tolerance. Frontiers of Plant Science, vol. 7, pp. 1341. http:// dx.doi.org/10.3389/fpls.2016.01341. PMid:27679640.

HUANG, K.-L., LIAO, L.-J., SHEN, R.-S., CHEN, W.-S. and LIN, Y.-H., 2002. The synergistic effect of maleic acid hydrazide (1.2-dihydro-3, 6-pyridazinedione) and sucrose on vase life of cut roses. Australian Journal of Experimental Agriculture, vol. 42, no. 5, pp. 637-641. http://dx.doi.org/10.1071/EA01101.

HUSSEIN, H., 1993. Varietal responses of cut flowers to different antimicrobial agents of bacterial contamination and keeping quality. Acta Horticulturae, vol. 368, pp. 106-116.

JONES, R.B. and HILL, M., 1993. The effect of germicides on the longevity of cut flowers. Journal of the American Society for Horticultural Science, vol. 118, no. 3, pp. 350-354. http://dx.doi. org/10.21273/JASHS.118.3.350.

KAZEMI, M. and AMERI, A., 2012. Extending the vase life of carnation with different preservatives. International Journal of Botany, vol. 8, no. 1, pp. 50-53. http://dx.doi.org/10.3923/ ijb.2012.50.53.

KHALID, N., NOMAN, A., AQEEL, M., MASOOD, A. and TUFAIL, A., 2019. Phytoremediation potential of Xanthium strumarium for heavy metals contaminated soils at roadsides. International Journal of Environmental Science and Technology, vol. 16, no. 4, pp. 2091-2100. http://dx.doi.org/10.1007/s13762-018-1825-5.

KHALID, N., NOMAN, A., SANAULLAH, T., AKRAM, M.A. and AQEEL, M., 2018. Vehicle pollution toxicity induced changes in physiology, defence system and biochemical characteristics of Calotropis procera L. Chemistry and Ecology, vol. 34, no. 6, pp. 565-581. http://dx.doi.org/10.1080/02757540.2018.1452917.

KNEE, M., 2000. Selection of biocides for use in floral preservatives. Postharvest Biology and Technology, vol. 18, no. 3, pp. 227-234. http://dx.doi.org/10.1016/S0925-5214(99)00074-5.

LEE, H., 2000. Principles and experimental techniques of plant physiology and biochemistry. Beijing: Higher Education Press.

LI, H., 2000. The experimental principle and technology of plant physiology and biochemistry. Higher Education Press, vol. 123124, pp. 186191.

LI, H., SUN, Q., ZHAO, S.J., and ZHANG, W.H., 2000. Principles and techniques of plant physiological biochemical experiment. Beijing: Higher Education, pp. 195-197.

LIU, J., HE, S., PEI-TAO, L., CAO, J., SHENG, A., ZHANG, Z., 2009. Effect of sodium dichloroisocyanurate on preservation of cut carnation (Dianthus caryphyllus L.). Yuan Yi Xue Bao, vol. 36, no. 1, pp. 121-126.

LOUBAUD, M. and VAN DOORN, W.G., 2004. Wound-induced and bacteria-induced xylem blockage in roses, Astilbe, and Viburnum. Postharvest Biology and Technology, vol. 32, no. 3, pp. 281-288. http://dx.doi.org/10.1016/j.postharvbio.2003.12.004.

LÜ, P., CAO, J., HE, S., LIU, J., LI, H., CHENG, G., DING, Y. and JOYCE, D.C., 2010. Nano-silver pulse treatments improve water relations of cut rose cv. Movie Star flowers. Postharvest Biology and Technology, vol. 57, no. 3, pp. 196-202. http://dx.doi. org/10.1016/j.postharvbio.2010.04.003.

MOSTOFA, M.G., HOSSAIN, M.A., SIDDIQUI, M.N., FUJITA, M. and TRAN, L.S., 2017. Phenotypical, physiological and biochemical analyses provide insight into selenium-induced phytotoxicity in rice plants. Chemosphere, vol. 178, pp. 212-223. http://dx.doi. org/10.1016/j.chemosphere.2017.03.046. PMid:28324842.

NOMAN, A., ALI, Q., MAQSOOD, J., IQBAL, N., JAVED, M.T., RASOOL, N. and NASEEM, J., 2018. Deciphering physio-biochemical, yield, and nutritional quality attributes of water-stressed radish (Raphanus sativus L.) plants grown from Zn-Lys primed seeds. Chemosphere, vol. 195, pp. 175-189. http:// dx.doi.org/10.1016/j.chemosphere.2017.12.059. PMid:29268176.

NOMAN, A., AQEEL, M., DENG, J., KHALID, N., SANAULLAH, T. and SHUILIN, H., 2017. Biotechnological advancements for improving floral attributes in ornamental plants. Frontiers of Plant Science, vol. 8, pp. 530. http://dx.doi.org/10.3389/fpls.2017.00530. PMid:28473834.

NOWAK, J., 1990. Postharvest handling and storage of cut flowers, florist greens, and potted plants. Oregon: Timber.

ONOZAKI, T., 2018. Breeding of carnations (Dianthus caryophyllus L.) for long vase life. Breeding Science, vol. 68, no. 1, pp. 3-13. http://dx.doi.org/10.1270/jsbbs.17091. PMid:29681743.

PERIK, R.R., RAZÉ, D., HARKEMA, H., ZHONG, Y. and VAN DOORN, W.G., 2012. Bending in cut Gerbera jamesonii flowers relates to adverse water relations and lack of stem sclerenchyma development, not to expansion of the stem central cavity or stem elongation. Postharvest Biology and Technology, vol. 74, pp. 11-18. http://dx.doi.org/10.1016/j.postharvbio.2012.06.009.

PUN, U., SHIMIZU, H., TANASE, K., ICHIMURA, K., 2003. Effect of sucrose on ethylene biosynthesis in cut spray carnation flowers. In: Proceedings of the Eighth International Symposium 
on Postharvest Physiology of Ornamental Plants, 10 August 2003, Doorwerth, Netherlands. Belgium: ISHS, pp. 171-174.

PUT, H.M.C., CLERKX, A., and DURKIN, D., 2000. Anatomy of cut Rosa xylem observed by scanning electron microscope. In: Proceedings of the Third International Symposium on Rose Research and Cultivation, 21 May 2000, Herzliya. Belgium: ISHS, pp. 331-339.

RAZA, A., IQBAL, N., MAHMOOD, S., PARVEEN, S., AZEEM, M., NAWAZ, M., JAVED, M.T. and NOMAN, A., 2018. Harnessing natural colorants for sustainable textile dyeing an eco-friendly approach using sweet cane (Saccharum bengalense Retz.) inflorescence. Brazilian Archives of Biology and Technology, vol. 61, no. 0, pp. 61. http://dx.doi.org/10.1590/1678-4324-2018170802.

SAEED, T., HASSAN, I., ABBASI, N.A. and JILANI, G., 2016. Antioxidative activities and qualitative changes in gladiolus cut flowers in response to salicylic acid application. Scientia Horticulturae, vol. 210, pp. 236-241. http://dx.doi.org/10.1016/j. scienta.2016.07.034.

SHABANIAN, S., ESFAHANI, M.N., KARAMIAN, R. and PHAN TRAN, L.-S., 2018. Physiological and biochemical modifications by postharvest treatment with sodium nitroprusside extend vase life of cut flowers of two gerbera cultivars. Postharvest Biology and Technology, vol. 137, pp. 1-8. http://dx.doi.org/10.1016/j. postharvbio.2017.11.009.

SHABNAM, N., TRIPATHI, I., SHARMILA, P. and PARDHASARADHI, P., 2016. A rapid, ideal, and eco-friendlier protocol for quantifying proline. Protoplasma, vol. 253, no. 6, pp. 1577-1582. http://dx.doi.org/10.1007/s00709-015-0910-6. PMid:26573534.

SOAD, M., LOBNA, S.T. and RAWIA, A.E., 2011. Extending postharvest life and keeping quality of Gerbera cut-flowers using some chemical preservatives. Journal of Applied Sciences Research, vol. 7, no. 7, pp. 1233-1239.

VAN DOORN, W. and D'HONT, K., 1994. Interaction between the effects of bacteria and dry storage on the opening and water relations of cut rose flowers. The Journal of Applied Bacteriology, vol. 77, no. 6, pp. 644-649. http://dx.doi.org/10.1111/j.1365-2672.1994. tb02814.x.
VAN DOORN, W.G., 2012. Water relations of cut flowers: An update. Horticultural Reviews, vol. 40, pp. 55-106. http://dx.doi. org/10.1002/9781118351871.ch2.

VAN DOORN, W.G., DE WITTE, Y. and HARKEMA, H., 1995. Effect of high numbers of exogenous bacteria on the water relations and longevity of cut carnation flowers. Postharvest Biology and Technology, vol. 6, no. 1-2, pp. 111-119. http:// dx.doi.org/10.1016/0925-5214(94)00043-R.

VAN IEPEREN, W., NIJSSE, J., KEIJZER, C.J. and VAN MEETEREN, U., 2001. Induction of air embolism in xylem conduits of pre-defined diameter. Journal of Experimental Botany, vol. 52, no. 358, pp. 981-991. http://dx.doi.org/10.1093/ jexbot/52.358.981. PMid:11432915.

YUPING, Z., 2009. Effects of salicylic acid on fresh keeping of cut Gerbera jamesonii flower. Anhui Agricultural Science Bulletin, vol. 13 .

ZAFAR, S., HASNAIN, Z., ANWAR, S., PERVEEN, S., IQBAL, N., NOMAN, A. and ALI, M., 2019. Influence of melatonin on antioxidant defense system and yield of wheat (Triticum aestivum L.) genotypes under saline condition. Pakistan Journal of Botany, vol. 51, no. 6, pp. 1987-1994. http://dx.doi.org/10.30848/PJB2019-6(5).

ZHANG, H., HU, S.-L., ZHANG, Z.-J., HU, L.-Y., JIANG, C.X., WEI, Z.-J., LIU, J., WANG, H.-L. and JIANG, S.-T., 2011. Hydrogen sulfide acts as a regulator of flower senescence in plants. Postharvest Biology and Technology, vol. 60, no. 3, pp. 251-257. http://dx.doi.org/10.1016/j.postharvbio.2011.01.006.

ZHAO, S., XU, C., ZOU, Q. and MENG, Q.W., 1994. Improvements of method for measurement of malondialdehyde in plant tissues. Plant Physiology Communications, vol. 30, no. 3, pp. 207-210.

ZHAO, Z.P., JIA, A.P., JIN, H., WANG, H.-L., and ZHANG, J.-J., 2016. Effect of different fresh-keeping agents on physiological and biochemical characteristics of Carnation cut flower. Heilongjiang Nongye Kexue, no. 8, pp. 68-71. 